\title{
COLLECTING DUCT CARCINOMA AND ENDEMIC NEPHROPATHY - CASE REPORTS AND LITERATURE REVIEW
}

\author{
Matej Knežević ${ }^{1}$, Karla Tomić ${ }^{2}$ Damir Dittrich ${ }^{3}$, Ivana Vuković Lela ${ }^{4,5}$, \\ Boris Ružić1,4, Borislav Spajić ${ }^{1,4}$, Krešimir Karlović ${ }^{3}$ and Goran Štimac ${ }^{1}$ \\ ${ }^{1}$ Department of Urology, Sestre milosrdnice University Hospital Centre, Zagreb, Croatia; \\ ${ }^{2}$ Department of Pathology, Dr Josip Benčević General Hospital, Slavonski Brod, Croatia; \\ ${ }^{3}$ Department of Urology, Dr Josip Benčević General Hospital, Slavonski Brod, Croatia; \\ ${ }^{4}$ School of Medicine, University of Zagreb, Zagreb, Croatia; \\ ${ }^{5}$ Department of Nephrology, Arterial Hypertension and Dialysis, Zagreb University Hospital Centre, Zagreb, Croatia
}

\begin{abstract}
SUMMARY - Although collecting duct carcinoma is a subtype of renal cell carcinoma, several studies implicate association with urothelial carcinoma. The coexistence of collecting duct carcinoma and another renal neoplasm is rare. Endemic nephropathy is a renal disease causing chronic renal failure. It is highly associated with urothelial neoplasm and occurs in endemic villages in Bosnia, Croatia, Bulgaria, Romania and Serbia. Recent studies have confirmed the important role of exposure to aristolochic acid as an etiologic factor. We present three cases of collecting duct carcinoma with literature overview. In one case, we describe collecting duct carcinoma with metachronous urothelial carcinoma of the pyelon and urinary bladder in an endemic nephropathy patient. To our knowledge, this is the first case report describing this coexistence. Certain similarities between collecting duct carcinoma and urothelial carcinoma were found, e.g., higher incidence in female compared to male, higher mean age, and multifocal and multicentric occurrence of the tumor. Our observations support the hypothesis that collecting duct carcinoma and urothelial carcinoma could be connected.
\end{abstract}

Key words: Collecting duct carcinoma; Bellini duct carcinoma; Endemic nephropathy; Kidney neoplasm; Renal failure; Urothelial carcinoma

\section{Introduction}

Collecting duct carcinoma (CDC) or Bellini duct carcinoma is a rare epithelial neoplasm of the kidney that accounts for $0.4 \%$ to $2.6 \%$ of all renal neoplasms ${ }^{1}$. These tumors behave in an aggressive manner with metastatic spread in one-third of patients at the time of diagnosis ${ }^{2,3}$. It predominantly occurs in younger male patients (mean age at diagnosis 43 years, male to female ratio $(\mathrm{M} / \mathrm{F}) 2: 1)^{4}$. Endemic nephropathy (EN) is a renal disease affecting inhabitants of rural areas in

Correspondence to: Matej Knežević, MD, Department of Urology, Sestre milosrdnice University Hospital Centre, Vinogradska c. 29, HR-10000, Zagreb, Croatia

E-mail: matejknezevic1@gmail.com

Received February 7, 2016, accepted May 17, 2017
Bosnia, Croatia, Bulgaria, Romania and Serbia. It causes chronic renal failure and has strong association with the high incidence of urothelial carcinoma of the upper urinary system (UC) ${ }^{5}$. Recent studies confirmed the important role of exposure to aristolochic acid as the etiologic factor ${ }^{6}$.

\section{Case Reports}

\section{Case 1}

A 69-year-old woman from an endemic village presented with right renal colic and massive hematuria. Medical history revealed previous nephroureterectomy of the left kidney due to invasive UC of the renal pelvis (pT3, G2), consistent with EN. On ultrasound 

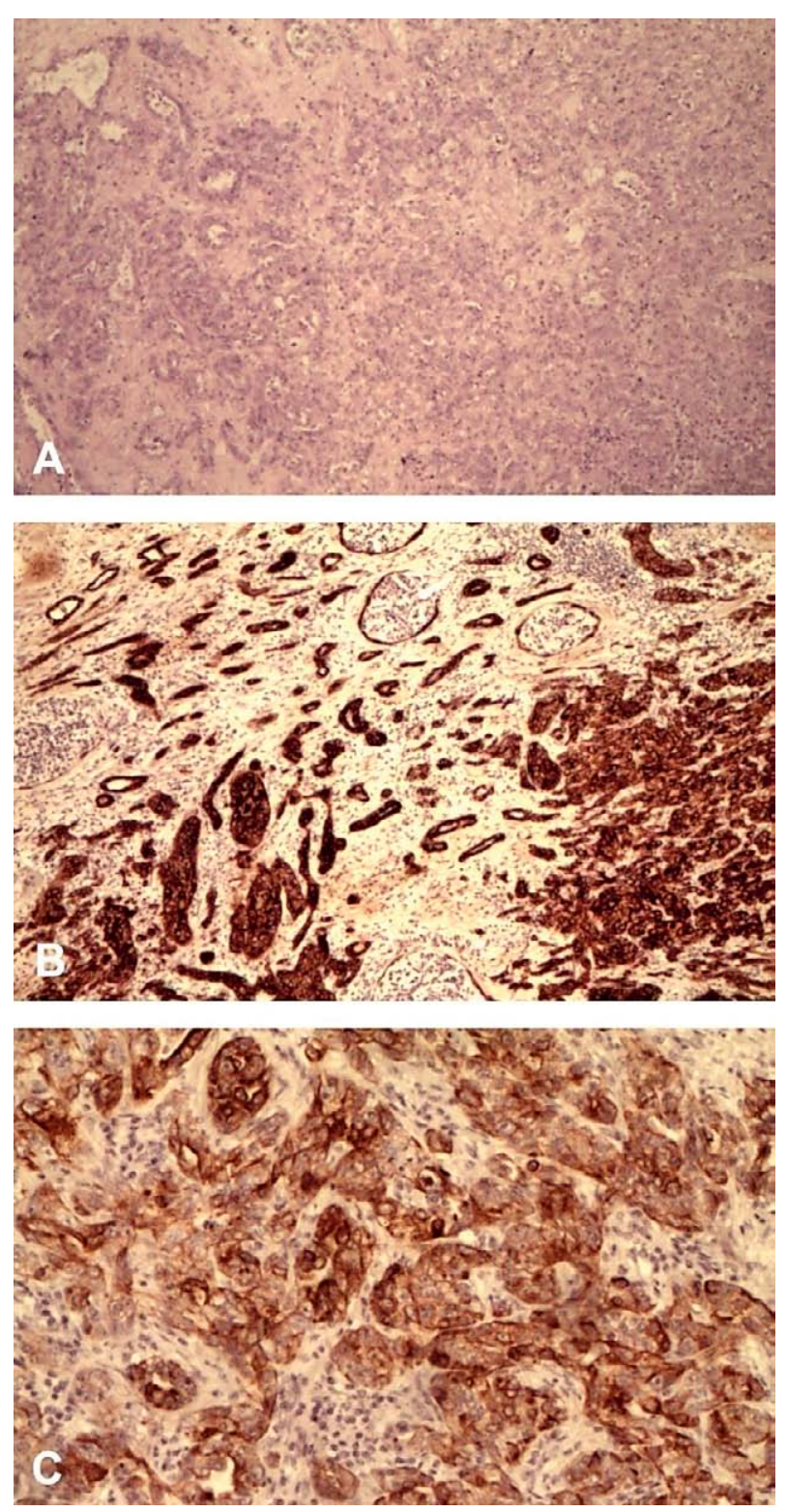

Fig. 1. Histologically, the tumor was composed of small tubules with highly atypical cells and marked desmoplastic stroma (hemalaun/eosin x100) (A); immunohistochemically positive $C K 7 \times 100$ (B); and $C K 34 \beta E 12 \times 200(C)$.

(US) and computer tomography (CT) scan, a tumor mass measuring $85 \times 65 \times 55 \mathrm{~mm}$ was found in the superior part of the contralateral right kidney. The patient underwent radical nephroureterectomy. Histologically, the tumor was composed of small tubules with highly atypical cells and marked desmoplastic stroma. Immunohistochemical analysis with CK7, CK34ßE12, CD10 and vimentin confirmed the diagnosis of CDC
(pT3, G2) (Fig. 1 A, B, C). Postoperatively, the patient was referred to hemodialysis and discharged home in good condition. After eight months, she was readmitted to the hospital due to severe hematuria. Cystoscopy revealed a tumor of the urinary bladder. Salvage cystectomy was performed. Histopathologic analysis showed UC (pT1, G2, high grade according to the World Health Organization (WHO) classification from 2004). The patient died 11 months after the initial diagnosis due to malignant disease.

\section{Case 2}

A 66-year-old male was admitted to the hospital due to lower urinary tract symptoms. Routine US described suspicious hypoechogenic zones in the right kidney, and CT confirmed a tumor mass measuring $44 \times 43 \mathrm{~mm}$. Radical nephrectomy was performed. Histopathologic examination with immunohistochemistry diagnosed CDC (pT3a, G4). After 10 days, the patient was discharged in a satisfactory condition. Due to poor general state, chemotherapy and radiotherapy were not indicated. Eight months after the initial diagnosis, the patient's condition deteriorated (with malaise and loss of weight) and the patient died.

\section{Case 3}

A female patient aged 61 suffering from hematuria and right lumbar pain was admitted. US showed a right kidney tumor. CT detected a soft tumorous mass measuring $40 \times 35 \times 30 \mathrm{~mm}$ in the lower and middle group of calices. Radical nephrectomy of the right kidney was performed. Imunohistologically, the tumor was diagnosed as Bellini duct carcinoma with positive regional lymph nodes (pT3N1, G3). Six days after surgery, the patient was discharged in good condition. Chemotherapy was administered (M-VAC protocol and sorafenib). The patient developed lung metastases after 10 months. Liver and bone metastases were found in additional 6 months. The patient died 18 months after the initial diagnosis due to primary disease.

All procedures performed in the studies involving human participants were in accordance with ethical standards of the institutional and/or national research committee and with the 1964 Helsinki Declaration and its later amendments or comparable ethical standards. An informed consent was obtained from all patients included in the study. 


\section{Discussion}

Collecting duct carcinoma is a rare neoplasm with $1 \%$ incidence of all renal tumors ${ }^{7}$. The coexistence with another renal neoplasm has been rarely described, usually with other subtypes of renal cell carcinoma (RCC) and $\mathrm{UC}^{8}$. According to the $\mathrm{WHO}, \mathrm{CDC}$ is a subtype of RCC, although some authors implicate association and similarities with $\mathrm{UC}^{9}$. The possible association of $\mathrm{CDC}$ and UC may reflect their common embryologic origin in Wolf's duct ${ }^{10}$. Our observations suggest some similarities between CDC and UC.

We analyzed all nephrectomy cases treated for renal and ureteral tumor at the Department of Urology in the endemic nephropathy region during the 20082010 period. During the study period, 84 cases were diagnosed as renal or ureteral tumor $(\mathrm{M} / \mathrm{F}=1: 1.27$, mean age 68.2). RCC was diagnosed in 29 cases (M/ $\mathrm{F}=1.63: 1$, mean age 63.9), UC in 52 cases (M/ $\mathrm{F}=1: 1.88$, mean age 74.3), and $\mathrm{CDC}$ in 3 cases (M/ $\mathrm{F}=1: 2$, mean age 66.6). The incidence of $\mathrm{CDC}$ in our Department was $3.57 \%$ of all renal tumors including upper urinary tract (pyelon, ureter), which was higher than expected concerning literature data ${ }^{10}$.

In Case 1, EN presenting with UC of the renal pelvis and urinary bladder occurred metachronously with CDC. To our knowledge, this is the first case report of this rare coexistence in the English literature. Nowadays, EN and UC are considered to be different clinical presentations of one disease that is influenced by exposure to aristolochic acid ${ }^{6}$. Following metabolic activation, aristolochic acid reacts with genomic DNA to form aristolactam-DNA adducts that generate a unique A:T to T:A transversions in the nontranscribed TP53 mutational spectrum. Therefore, these, otherwise rare mutations are a biomarker of exposure to aristolochic acid ${ }^{11}$.Upper UC is present in $50 \%$ of $\mathrm{EN}$ cases, while they account for only $5 \%$ of all urinary tract cancers worldwide 5 . Specific UC mortality in the EN region compared to Croatia is 55 times higher (with female predominance) ${ }^{12}$. Patients from endemic region with UC tend to have impaired kidney function. According to the modified WHO criteria, EN is defined by living in endemic region for more than 15 years, impaired kidney and anemia with exclusion of other causes of chronic kidney disease. Typical renal histopathology in early stages of EN shows extensive cortical tubular atrophy and dense interstitial fibrosis with gradient and little inflammation, but due to secondary changes, it is frequently insufficient for making the diagnosis of $\mathrm{EN}$ in older population. Our first case of a patient from a Bosnian endemic village met the EN criteria; according to the epidemiologic survey, the patient had been exposed to aristolochic acid, and apart from Bellini duct carcinoma, had UC of the pyelon and a severely reduced kidney function (eGFR 17 $\mathrm{mL} / \mathrm{min}$ ). Histopathologic examination also revealed chronic pyelonephritis with already advanced interstitial fibrosis. Tumor TP53 mutational spectrum, using p53 AmpliChip Technology, demonstrated specific A:T to T:A transversions, which are the biomarker of exposure to aristolochic acid, and consequently EN marker. Therefore, this is a unique case of two different rare conditions and urothelial tract tumors in the same patient.

Our analysis confirmed that in the EN region, UC occurs more frequently than RCC, with a female predominance and higher mean age at onset. It is also observed that $\mathrm{UC}$ in EN regions is more frequently bilateral, multifocal and multicentric ${ }^{13}$. CDC from our endemic region shared some similarities with UC, e.g., higher incidence in female than male, higher mean age, and metachronous urothelial carcinoma of the pyelon and urinary bladder in one patient. CDC might be distinct from conventional RCC but shares biologic features with UC, with consequent implications for its management ${ }^{9}$. Because of the close relationship between CDC and UC (a common embryologic origin that arises from the mesonephrons), CDC could also have similarities with UC from endemic region in risk factors and showing a higher incidence in endemic region.

The understanding of the CDC is still insufficient. It is a disease with poor prognosis, survival and response to target therapies ${ }^{3,14}$. The cases reported in this paper could contribute to deeper understanding of the rare CDC entity. Regarding this, our study supports the hypothesis that CDC and UC could be connected. Further larger studies on the possible connection to EN are needed.

\section{Conclusion}

The coexistence of CDC with other renal neoplasms is rare. We report the first case of CDC coexisting with UC of the pyelon and urinary bladder in an EN patient. Recently, aristolochic acid was confirmed as an etiologic factor for EN. On the other hand, the 
understanding of $\mathrm{CDC}$ is still insufficient. This report presents an intriguing connection between $\mathrm{CDC}$ and UC of the upper urinary tract. The cases reported in this paper could contribute to better understanding of the rare CDC entity.

\section{References}

1. Sehgal TA, Chowdhary PS, Singh DP, Thatte SW, Muzumdar G, Patel K. Bellini duct carcinoma. Bombay Hosp J. 2011;53: 99-102.

2. Srigley JR, Moch H. Carcinoma of the collecting ducts of Bellini. In: Eble NJ, Sauter G, Epstein JI, et al., editors. WHO Classification of Tumors of the Urinary System and Male Genital Organs. Lyon: IARC Press, 2004; p. 33-4.

3. Kruslin B, Glumbic I, Reljic A, Cupic H, Ruzic B, Stimac G, Belicza M. Collecting duct carcinoma of the kidney: report of three cases. Acta Clin Croat. 2001;40:21-5.

4. Staehler M, Schöppler G, Haseke N, et al. Carcinoma of the collecting ducts of Bellini of the kidney: adjuvant chemotherapy followed by multikinase inhibition with sunitinib. Clin Genitourin Cancer. 2009;7:58-61, https://doi.org/10.3816/ CGC.2009.n.010

5. Petronic V. Tumors of the upper urothelium and endemic nephropathy. In: Radovanovic Z, Sindic M, Polenakovic M, Djukanovic L, Petronic V, editors. Endemic Nephropathy. Belgrade, Serbia: Institute for Textbook Publishing, 2000; p. 350-439.

6. Jelakovic B, Karanovic S, Vukovic-Lela I, et al. AristolactamDNA adducts are a biomarker of environmental exposure to aristolochic acid. Kidney Int. 2012;81:559-67, https://doi. org/10.1038/ki.2011.371
7. Singh I, Nabi G. Bellini duct carcinoma: review of diagnosis and management. Int Urol Nephrol. 2002;34:91-5, https://doi. org/10.1023/a:1021315130481

8. Hart AP, Brown R, Leachago J, Troung DL. Collision of transitional cell carcinoma and renal cell carcinoma. An immunohistochemical study and review of the literature. Cancer. 1994;73:154-9, https://doi.org/10.1002/1097-0142(199401 01)73:1<154::aid-cncr2820730126>3.0.co;2-k

9. Orsola A, Trias I, Raventós CX, Español I, Cecchini L, Orsola I. Renal collecting (Bellini) duct carcinoma displays similar characteristics to upper tract urothelial cell carcinoma. Urology. 2005;65:49-54, https://doi.org/10.1016/j.urology.2004.08.012

10. Matei DV, Rocco B, Varela R, et al. Synchronous collecting duct carcinoma and papillary renal cell carcinoma: a case report and review of the literature. Anticancer Res. 2005;25:579-86.

11. Grollman AP, Shibutani S, Moriya M, et al. Aristolochic acid and the etiology of endemic (Balkan) nephropathy. Proc Natl Acad Sci U S A. 2007;104:12129-34, https://doi.org/10.1073/ pnas.0701248104

12. Miletic-Medved M, Domijan A, Peraica M. Recent data on endemic nephropathy and related urothelial tumors in Croatia. Wien Klin Wochenschr. 2005;17:604-9, https://doi.org/ 10.1007/s00508-005-0426-8

13. Belicza M, Demirović A, Tomić K, et al. Comparison of occurrence of upper urinary tract carcinomas in the region with endemic villages and non-endemic nephropathy region in Croatia. Coll Antropol. 2008;32:1203-7.

14. Husillos A, Herranz-Amo F, Subirá D, Lledó E, Molina-Escudero R, Hernández-Fernández C. Collecting duct renal cell carcinoma. Actas Urol Esp. 2011;35:368-71, https://doi. org/10.1016/j.acuro.2011.01.012

Sažetak

\section{KARCINOM SABIRNIH KANALIĆA I ENDEMSKA NEFROPATIJA - PRIKAZI SLUČAJA I PREGLED LITERATURE}

\section{Knežević, K. Tomic, D. Dittrich, I. Vuković Lela, B. Ružič, B. Spajić, K. Karlović i G. Śtimac}

Iako je karcinom sabirnih kanalića podvrsta karcinoma bubrežnih stanica, određena istraživanja ukazuju na povezanost ovog entiteta s karcinomom prijelaznog epitela. Istodobna pojava karcinoma sabirnih kanalića i drugih bubrežnih neoplazma je rijetka. Endemska nefropatija je bubrežna bolest koja dovodi do kroničnog bubrežnog zatajenja. Vrlo je povezana s urotelnim tumorima i javlja se u endemskim selima u Bosni, Hrvatskoj, Bugarskoj, Rumunjskoj i Srbiji. Nedavna istraživanja potvrdila su značajnu ulogu izloženosti aristolohičnoj kiselini kao etiološkom čimbeniku. Predstavljamo tri slučaja karcinoma sabirnih kanalića s pregledom literature. U jednom slučaju opisujemo karcinom sabirnih kanalića s metakronom pojavom urotelnog karcinoma pijelona te mokraćnog mjehura u bolesnika s potvrđenom endemskom nefropatijom. Prema našim saznanjima ovo je prvi slučaj koji opisuje ovakvu koegzistenciju. Pronađene su određene sličnosti između karcinoma sabirnih kanalića i karcinoma prijelaznog epitela, a to su veća učestalost u ženskoj populaciji, viša prosječna dob, multifokalna i multicentrična pojava tumora. Naša zapažanja podupiru hipotezu o mogućoj povezanosti karcinoma sabirnih kanalića i karcinoma prijelaznog epitela.

Ključne riječi: Karcinom sabirnih kanalić; Karcinom Bellinijeva kanalica; Endemska nefropatija; Bubrežna novotvorina; Bubrežno zatajenje; Karcinom urotela 